\title{
La importancia de un gusano volador: una invitación razonada y apasionada a la lectura del subgénero romántico de cuentos populares escritos
}

\author{
Ada Puerto \\ Universidad de Sevilla \\ adapuerto@gmail.com \\ https://dx.doi.org.10.12795/futhark.2016.il I.08
}

Fecha de recepción: 17.05.2016

Fecha de aceptación: 15.06.2016

Resumen: La literatura trivial es concebida de forma general como un género para la distracción y el divertimento, Este artículo nos presenta un subgénero de la misma y nos expone su importancia y sus valores escondidos tras cuentos populares reescritos con un toque más actual.

Palabras clave: literatura trivial, romanticismo, cuento popular, mujer

\section{The reason to choose a flying worm: a reasoned and passionate invitation to read the new rewritten popular tales minor genre}

\begin{abstract}
It is commonly believed that trivial literature is made to amuse and to entertain. This article introduces us to a trivial literature's minor genre and shows us the importance and principles behind popular tales rewritten with a more contemporary touch.
\end{abstract}

Key words: trivial literature, romance, popular tale, woman

Sumario: Introducción. I. El cuento y la mujer en la literatura trivial: nuevas perspectivas. Conclusiones. 


\section{Introducción}

El aspecto más atractivo de la literatura trivial' es el gran número de público al que accede ${ }^{2}$, mientras que cualquier otro tipo de literatura más seria no es tan leída $^{3}$. Bajo el nombre de trivial esta literatura puede poner a disposición de muchísimos lectores ideas importantes y complejas ${ }^{4}$, defender ideales ${ }^{5}$, promover

\footnotetext{
I "El término trivial aplicado a la literatura con frecuencia se ha unido al de entretenimiento, como queriendo sugerir que aquellos textos de carácter literario que buscan, prioritariamente, entretener, no pueden sino ser de escasa valía y relevancia. Si en los últimos años esta idea se está abandonando (...) porque en aquellos géneros, -la novela negra, romántica, de terror o ciencia-ficción, entre otras- se han comenzado a descubrir valores estéticos o de otro tipo tan trascendentales, que la idea de entretener empalidece frente a otras muchas intenciones halladas o declaradas de los autores." (Parra 20I3: 9)
}

${ }^{2}$ Y si hablamos de autores de novelas populares "rosas" hay que empezar nombrando, forzosamente, a Corín Tellado, y esto no es por la calidad de sus obras (...) sino por el impacto que tuvo entre el público lector femenino. (...) Y que la Unesco declarase que Corín Tellado era la autora más leída en castellano después de la biblia y Cervantes." (Charlo Ortiz-Repiso 2013: 210, 2II). Si buscamos en Amazon títulos considerados triviales como por ejemplo uno de la temática a debate, como es AschenKindel (Summer 2016) encontramos más de 600 reseñas.

${ }^{3}$ Los muy famosos pilares de Follet (Follet 1989) sin embargo y a pesar de ser un best seller, cuentan tan solo con 96 reseñas. Esto se debe quizás a su extensión o quizás a su temática más "seria" pero menos accesible para todos los lectores.

4 Como la imagen femenina renovada de la que hablo a continuación, la normalización de la homosexualidad, etc.

${ }^{5}$ Como por ejemplo revalorizar a las autoras y su capacidad de escribir algo más allá del campo que se les ha "permitido", es decir, la literatura romántica. Estos libros son una buena muestra de todo lo que tienen que decir las mujeres y de la importancia y la calidad que poseen sus escritos. "Now 'women's literature' usually refers to fiction and poetry written by women, sometimes also to the polemics of feminism from the late eighteenth century on; it also may be extended to women's letters, diaries, and autobiog raphies. This being so, it is easy to locate members of the category, but that is not to say that the category really exists as an object of study. (...) be. If one chose to be an English teacher, it was because one had an interest in literature; one didn't have to astonish the professors, or to decorate a campus, or to confine oneself to books on childbirth. If one chose to write fiction, it was because one wanted readers to say "What a fine novel," not "Oh, a woman!"'(Rae Amiran 1978: 653). Para ahondar en este tema vease: A Literature of Their Own: British Women Novelists from Bronte to Lessing (Showalter 1977), "Some Notes on Defining a 'Feminist Literary Criticism' (Kolodny 1975), "Feminism and Literary Study: A Reply to Annette Kolodny," (W. Morgan 1976). "Frauenliteratur (Women's literature): an untenable term after bare ly ten years? The voices that reject the concept today are just as vehe ment as those that not so very long ago pleaded for and propagated the new women's literature. Once again it is women who are leading the discussion. It almost seems as if, in the meantime, the advocates had switched places with the skeptics. While publishers have begun with their women's literature series, it is women writers who are renouncing their affiliation with women's literature. There is hardly a more con troversial concept in contemporary German literature." (Weigel 1984: 53). También es interesante el artículo The Myth of Judith Shakespeare: Creating the Canon of Women's Literature (Ezell 1990) respecto a este tema. 
algo concreto ${ }^{6}$ o simplemente y llanamente tener un tema trivial. Cuando un escritor de este tipo de literatura tiene algo que decir dispone también de un amplio número de lectores dispuestos a leerle y esto proporciona un gran poder y responsabilidad a dichos escritores.

Dentro del género romántico encontramos el subgénero de cuentos populares reescritos, un género relativamente poco conocido en España ${ }^{7}$. ¿Por qué debemos considerar este subgénero digno de nuestro interés? ¿Qué tiene que decirnos? Pues bien, podemos empezar pensando en lo antiguos que son estos cuentos populares ${ }^{8}$ y preguntarnos cuánto tiempo les queda entre nosotros. Muchos empiezan a estar un tanto obsoletos ${ }^{9}$ y la mayoría tienen algún o algunos aspectos que no acompañan ya los valores de nuestro tiempo, como por ejemplo la imagen de la mujer que se presenta en ellos, esa clásica mujer de cuento, película o serie tradicional ${ }^{10}$. Mujeres que necesitan un hombre para estar completas ${ }^{\prime \prime}$,

6 “(...) la saga de Harry Potter ha reconciliado con la lectura a millones de adolescentes más inclinados hacia otros medios de entretenimiento, deberíamos preguntarnos, ¿por qué? ¿Qué les proporciona esta literatura -pues como tal reivindico lo trivial, como se comprenderá por lo antedicho- a estas masas, qué influye en ellas hasta el punto de modificar hábitos y comportamientos? ¿Cómo logra el texto literario -e insisto de nuevo que lo es- tocar las mentes de masas de lectores y transformarlos? ¿Qué recursos emplea? ¿No debemos pensar que éstos son más estéticos que económicos? ¿Y no es eso arte?" (Parra 2013: 21)

${ }^{7} \mathrm{Si}$ hacemos una búsqueda rápida en Amazon.es de una de las autoras más famosas de este subgénero, como es Marissa Meyer, sus libros tiene tan solo de 4 a 9 comentarios o valoraciones. Eso sí, todas ellas muy positivas. Sin embargo si realizamos la misma búsqueda en Amazon.de nos encontramos con alrededor de 99 o 174 valoraciones dependiendo de la novela.

${ }^{8}$ Kinder- und Hausmärchen (Grimm 1912, Grimm 1915).

${ }^{9}$ Es interesante leer el artículo F. M. Grimm and the Eighteenth-Century Debate on Women (Schwartz 1984).

10 "One may, nevertheless, argue that there are feminine subjects, that literature is an imitation of life, and that society and biology have decreed that women shall have concerns which are different from men's. Women have been made prisoners; they have suffered from powerlessness, from loss of identity, from conflicts over self-assertion and a professional career. Their lives have centered around the home: they have been forced to concern themselves with catching and keeping a husband, raising children, and finding something to do with themselves after their children are grown. In this connection, it is interesting to notice how few major novels have dealt with the day-to-day problems and worries of raising children, a subject necessarily of great concern to women, if not to men as well." (Rae 1978: 656).

II "En cualquier caso las novelas románticas tienen un solo tema, el amor, y se circunscriben a contar las peripecias de ese amor: su nacimiento, su desarrollo y su culminación. En un principio esta culminación solo se alcanzaba a través del matrimonio, aspiración final de casi todas las mujeres. Las novelas relataban los sucesos que afectaban a los protagonistas del amor que se contaba y las diferentes etapas por las que pasaba este. Rara vez se profundizaba con una exposición de los sentimientos, y por supuesto el deseo carnal brillaba por su ausencia, la pasión no existía (...)” (Charlo 20I3: I0I). 
mujeres sometidas a cánones de belleza totalmente crueles y absurdos ${ }^{12}$, mujeres que tienen que asistir a bailes llenos de otras mujeres y competir entre ellas para llevarse el gran premio: un hombre ${ }^{13}$. Mujeres que odian a otras mujeres más guapas, pero no odian al príncipe que organiza bailes para hacer estudios de mercado femenino. Mujeres con "sentimientos de mujeres" y hombres "sentimientos de hombres" 14 . Y sobre todo mujeres sin deseos sexuales o pasión alguna'.

\begin{abstract}
12 Hasta el punto de necesitar de la magia para ser lo suficientemente atractiva para el príncipe. Para saber más sobre este tema vid. The Female Body, Work, and Reproduction in Deland, Cather, and Dreiser (Marquis 2003). "The second half of the nineteenth century, as Kathy Peiss notes, operated under a general discomfort toward women and their outward appearances; the feminist movement left many-particularly men-concerned that women would not simply become more masculine physically as their identities became more associated with the ideas of women's rights, but that they would depart from femininity altogether. Both Enstad and Laura Behling emphasize the concern raised by the suffragist movement as to how far a woman could go into the masculine domain and still be considered a woman." (Maquis 2003: 98I)
\end{abstract}

"However, traditional physical beauty was generally represented in the literature of the nineteenth century, which "bound the feminine to ideals of sexual chastity and transcendent purity" (Peiss 24). Such purity is indubitably linked to the little expected of women in terms of "masculine" domains, such as sexual prowess or nondomestic work. Specifically, this had implications for feminine physicality of a leisure class; white, weak hands, for example, were representative of a woman who not only did not work, but also did not have to. Furthermore, modes of beauty at the time were being determined by the growth of a consumer culture, as both Peiss and Enstad note, that required women to dress appropriately to be considered "ladies" and that provided women with the means -such as a relatively new cosmetics industry - to do so". (Maquis 2003: 982)

13“"Moment mal... sagtest du gerade, es kommen alle ledigen jungen Frauen des Königreichs?”. “Ja. Er möchte jede Einzelne von ihnen kennenlernen und schreckt nicht davor zurück, ein einfaches Mädchen zu ehelichen. Ist das nicht romantisch?". (Summer 2016).

14 "Emotions found to a greater degree in men are excitement, disgust, anger, readiness to cause surprise, and boldness, all of which are active emotions of relatively low pleasantness. Emotions found to a greater degree in women are friendliness, joy, surprise, distress, and shame, all of which are less active emotions and also, in the case of friendliness and joy, more pleasant emotions. Both models take note of the greater importance of the pleasantness dimension to women's emotions and of the activation dimension to men's emotions" (Mosher \& Maclan 1994; Whissell \& Chellew 1994: 148)

15 "La frigidez de la mujer se traduce por la ausencia de deseos, como si las relaciones sexuales normales no les dijesen nada. (...) Corrientemente se cree que la frigidez proviene del temperamento o de un defecto de conformación física: en la mayor parte de los casos, eso es exacto." (Edith 1963: I53). Es también interesante para conocer más sobre este tema leer el artículo Grand Hotel: The Sexual Politics of a Popular Culture Classic (King 2000) donde encontramos reflexiones sobre Menschen im Hotel (Baum 1929) como la siguiente: "In the 1029 novel, Flämmchen unsentimentally views her beautiful body as a commodity to exchange for money, food, and clothing. In her class-determined universe, true love does not exist, and she certainly cannot wait for a fary-tale man to rescue her, so she accepts Preysing's offer without much fuss."(King 2000: 188) 


\section{El cuento y la mujer en la literatura trivial: nuevas perspectivas}

Por fin ha llegado el momento en que la mujer no quiere que la protagonista sea la más guapa del cuento, que la mala sea la más fea, que el hada bonachona sea regordeta y que las hermanastras sean idiotas. Nos cansa esa imagen femenina de la mujer que espera con el asado en el horno a que el marido llegue de trabajar. Nos cansa que el príncipe mirase tan poco a Cenicienta a la cara que para encontrarla tuviese que ir con el zapatito por todo el reino. ¿Dónde estuvo mirando toda la noche? ¿Un poco más abajo del rostro quizás? Estos cuentos nos han acompañado a todas desde nuestra infancia, a nosotras, a nuestras madres, a sus madres, etc $y$ por eso sería una pena que se fuesen olvidando solo por haber sido creados hace mucho tiempo. Es una buena solución darles ese nuevo toque más contemporáneo e introducir en ellos unos nuevos valores más acordes con la época para salvarles la vida. Este subgénero es un subgénero héroe que rescata a estos pobres cuentos $^{16}$.

${ }^{16}$ Es muy interesante saber que estos cuentos que ahora conocemos no tienen en realidad mucha similitud con los originales y que de hecho no podría decirse en realidad cuál es el cuento original, ya que existen innumerables versiones y de hecho existen en otros lugares de Europa relatos similares. Este fenómeno hace no tenga mucho sentido hablar de un relato original. "As collections of the same type grew increasingly numerous and made European folklore better known, some extremely precise similarities were discovered among the tales, resemblances whose very constancy was such that it ruled out any explanation by fortuitous encounter. Indeed, not only did the nar ratives from highly diverse countries have a common plot, their elements were also identically arranged and combined, with the ex ception of a few variants- but these still underscored a clear con tinuity of the themes. How can such similarities be explained other wise than by a common origin? But, once raised, the question of the origin and dissemination of the tales raised also the question of their possible meaning. For if these stories had passed from generation to generation, starting from a single origin, it was dif ficult to consider them as altogether absurd. On the contrary, it was necessary to believe that they had indeed had a meaning, which had naturally grown obscure as they moved ever further from their distant beginnings. In order to elucidate these problems, which caused the tales to lose their apparently harmless nature, the Grimm Brothers formulated an attractive theory which was long held to correspond to truth. In their capacity as philologists mainly preoccupied with the origins of their language, they were led to think that all the marvelous narratives forming the foundation of European folklore are of Aryan origin, and are to be regarded as more or less pale or vivid reflections of myths conceived in time immemorial by the race from whom the Hindus, the Persians, the Greeks, the Romans and most of the peoples of Europe are descended." (Robert 1969: 45). Y respecto al desconocimiento general sobre los relatos de los hermanos Grimm (Grimm 18I2) hoy en día podemos leer a continuación el final de Aschenputtel (Grimm 19/2) a la que hoy día conocemos como Cenicienta: "Und als sie das gerufen hatten, kamen sie beide herabgeflogen und setzten sich dem Aschenputtel auf die Schultern, eine rechts, die andere links, und blieben da sitzen. Als die Hochzeit mit dem Königssohn sollte gehalten werden, kamen die falschen Schwestern, wollten sich einschmeicheln und teil an seinem Glück nehmen. Als die Brautleute nun zur Kirche gingen, war die älteste zur rechten, die jüngste zur linken Seite: da pickten die Tauben einer jeden das eine Auge aus. Hernach, als sie herausgingen, war die älteste zur linken und die jüngste zur rechten: da pickten die Tauben einer jeden das andere Auge aus. Und waren sie also für ihre Bosheit und Falschheit mit Blindheit auf ihr Lebtag bestraft." (Grimm 1912: II6). Para conocer el maravilloso trabajo de los hermanos Grimm y valorarlo adecuadamente ver Oral tradition and the brothers Grimm (Michaelis-Jena 197I). "We are used to labelling people, to seeing 
Estas novelas no solo rescatan a los cuentos sino que también rescatan a las niñas y niños que hay en nosotros. Ya somos adultos, o lo parecemos, y no nos permitimos mucho tiempo para soñar en nuestra aburrida y adulta vida, no llevamos nuestros cuentos de infancia con nosotros y los releemos para volver a ser pequeños por un rato. A veces todos podemos necesitar volver a esa época, es muy importante no encerrar al niño o niña que hemos sido en un rincón de nuestro interior, pero otras veces parece que se considere una debilidad seguir disfrutando de placeres infantiles. Por eso es genial que existan libros que, aunque de un modo un poco más adulto, nos devuelva a esos mundos fantásticos y nos haga sentir de nuevo todas esas cosas que sentimos con esos cuentos en el pasado. Quizás podría dar un aspecto un poco extraño un adulto que va leyendo en el tren Caperucita roja, pero con este subgénero podremos llevar cualquier cuento popular con nosotros y leerlo con satisfacción como cualquier otro tipo de novela.

Es un tema muy a la orden del día la importancia de mantener relaciones sociales $y$ afectivas sanas $y$ equilibradas ${ }^{17}$. Al cambiar la mentalidad de las protagonistas estas novelas crean inevitablemente un nuevo modo en que ella se relaciona con el resto de personajes. Antes la protagonista era casi odiosamente sumisa, obediente, se autocompadecía de su desdicha y soñaba con que un hombre entrase en su vida y solucionase todos sus males. La chica no se planteaba si el

their 'image', and it is perhaps not astonishing that our immediate response to 'the Brothers Grimm' should be 'fairytales'. Yet the more serious emphasis has always been on Jacob's and Wilhelm's work as philologists, as founders of the study of Germanic languages and literature, while their reputation as collectors of folklore material has fluctuated between praise and depreciation. Gradually a more balanced judgment is gaining ground, and the Grimms' remark able work in the gathering of oral traditions is more fully appreci ated. It may in time be remembered as their greatest achievement. They are the true begetters of Marchenforschung, pioneers and unique, seen in the context of their time" (Michaelis- Jena 1971: 275). Si se desea saber más sobre los Märchen cultivados por los hermanos Grimm es muy interesante el artículo The German Romantic "Märchen” (Herndon Fife I9II). "Wilhelm and Jacob Grimm began to get together the great collection which they afterward published as Kinderund Haus marchen. In 1808 Arnim's Einsiedlerzeitung published, along with many other fragments of folklore, Runge's "Marchen vom Machan delboom," which with its simple, naive style gave the chord for the Grimms in their rewriting of the popular stories, and drew a line at once between the Volksmarchen, a retelling in the simple narra tive manner of the peasantry, and the Kunstmarchen, including the essentially original productions of Novalis and the subjective, capricious re-creations of the popular Marchen by Tieck and Bren tano. In 1812, a momentous year for the history of the Mirchen, appeared the first volume of Grimms' collection and somewhat earlier the collection of their rival BiischingVolkssagen, Mdrchen und Legenden-while Tieck's Phantasus, with its new and old stories, gave fresh impetus to the Kunstmiirchen. Indeed, it is difficult to exaggerate the interest and activity in the entire field of Marchen dichtung during the first and second decades of the century. Hoff mann's Meister Floh, appearing in 1821 , shows the enthusiasm for the ironical Ma*rchen as a vehicle for satire still at the flood; and one has but to glance into the Taschenbiicher and Almanache and other periodicals of the time to find all possible varieties of the Marchen form." (Herndon Fife I9II: 3 )

17 Non Violence Communication: A Language of Life (Rosenberg 1998), Alternatives to Violence: Empowering Youth To Develop Healthy Relationships (Wolfe, Wekerle, Scott 1997). 
príncipe le gustaba, no se planteaba que era el único hombre de su edad al que había conocido, no se planteaba si lo quería o no, ella no elegía, no pensaba, no tenía otro papel que el de existir.

Nun warf ihm der Vogel ein Kleid herab, das war so prächtig und glänzend, wie es noch keins gehabt hatte, und die Pantoffeln waren ganz golden. Als es in dem Kleid zu der Hochzeit kam, wußten sie alle nicht, was sie vor Verwunderung sagen sollten. Der Königssohn tanzte ganz allein mit ihm, und wenn es einer aufforderte, sprach er »das ist meine Tänzerin."Als es nun Abend war, wollte Aschenputtel fort, und der Königssohn wollte es begleiten, aber es entsprang ihm so geschwind, daß er nicht folgen konnte. Der Königssohn hatte aber eine List gebraucht, und hatte die ganze Treppe mit Pech bestreichen lassen: da war, als es hinabsprang, der linke Pantoffel des Mädchens hängen geblieben. Der Königssohn hob ihn auf, und er war klein und zierlich und ganz golden. Am nächsten Morgen ging er damit zu dem Mann und sagte zu ihm "keine andere soll meine Gemahlin werden als die, an deren Fuß dieser goldene Schuh paßt". (Grimm 1912: 114)

En este nuevo tipo de cuento la protagonista podríamos ser todas nosotras y el príncipe podría ser cualquiera de los lectores. Ninguno es perfecto, ninguno pretende serlo y ambos tienen sus propios gustos, ideales, pensamientos y caracteres. Más creíble, podemos sentirnos identificados, podemos entenderlos y tenemos esos mismos problemas. Nos muestra una relación mucho más sana, más equilibrada y realista. Del mismo modo las relaciones de amistad de los libros son mucho más complejas, ahora la protagonista tiene amigos. Ya sea un hada o un gusano volador, pero por fin estas chicas tienen verdaderos amigos con los que se ríen, enfadan y discuten. Un mundo fantástico mucho más agradable y en el que de verdad querríamos estar. Las protagonistas se esfuerzan por sus amigos, hacen cosas por ellos e incluso se sacrifican por ellos. En general son novelas que de un modo u otro defienden unos valores mucho más sanos. Se acabó el concepto de: el único fin de mi vida es el matrimonio.

Pero el amor es el amor y todos queremos amor. No como fin último de nuestra existencia, pero sí como complemento a nuestra ya perfecta existencia ${ }^{18}$. El es gran tema del arte y por algo será y siempre querremos leerlo, verlo o escucharlo aunque ahora de un modo más sano. Y esto me lleva al siguiente punto a favor de estas obras, el humor. El humor es otro de esos temas o recursos que nunca pasan de moda, evolucionan, pero no caducan. A todos nos gusta reírnos, a

\footnotetext{
${ }^{18}$ Es una muy buena noticia que ya no se bombardee al lector o lector (en algunas novelas) con la idea de que para ser completamente felices necesitan algo o a alguien más. Es mucho más sano y positivo que se comience a hablar del amor como un complemento a una felicidad que nos proporcionamos ya nosotros mismos. Esto ayuda a crear una imagen más equilibrada del mismo, el lector no se sentirá vacío sin ese amor, no sentirá que no es suficiente para sí mismo.
} 
todos nos gusta el amor y sobre todas las cosas a todos nos gusta reírnos del amor, del objeto de nuestro amor y de nosotros mismo. Por esto mismo, estas novelas dan un tinte más cómico al amor y pueden captar lectores que normalmente no leerían novela romántica. Es una forma de acceder a más lectores y de romper un poco con los típicos clichés de la novela romántica más tradicional.

\section{Conclusiones}

Así que tenemos feminismo, amor propio, amistad real, humor, amor más realista, temas serios escondidos bajo un aspecto trivial, una nueva oportunidad a cuentos un poco pasados de moda y una oportunidad para ser niños de nuevo. Podemos decir que es un tipo de literatura que tiene mucho que ofrecernos y que merece que le demos una oportunidad. Si aun así todo esto no parece suficiente, es importante saber que hay muchos autores diferentes que reescriben estos cuentos y esto nos proporciona muchas nuevas versiones de un solo cuento. Si uno no te ha gustado lo suficiente no tienes que renunciar al subgénero porque encontrarás otros. Si te gustan los gusanos voladores ${ }^{19}$, las mascotas en general, los cyborgs, plagas mortales, habitantes lunares, hackers, hombres lobos, investigaciones policiales, mafias, etc ${ }^{20}$, no existe límite. Cualquier lector tiene cabida en estas novelas que crean infinitas posibilidades.

\section{Referencias bibliográficas}

Bibliografia primaria

BAUM, V. (1929). Menschen im Hotel. Hamburg: Zeitverlag Gerd Bucerius GmbH \& Co.

CARNOT, E. (1963). El libro de la joven. Madrid: Stvdivm

Follet, K. (1989). The Pillars of the Earth. New York: Penguin Random House. Macmillan

GrIMM, W.; Grimm, J. (19/2). Kinder und Hausmärchen. Darmstadt: Wissenschaftliche Buchgesellschaft.

MeYER, M. (2016). The Lunar Chronicles. New York: Square Fish

ROSENBERG, M. (1998). Non Violence Communication: A Language of Life. Disponible en: https://books.google.es/books?hl=es\&lr=\&id=A3qACgAAQBA|\&oi=fnd\&pg =PT22\&dq=Non+Violence+Communication+A+language+of+Life+Rosenb erg+\&ots $=$ ch3hQolUm4\&sig=XNLFYbRe4sElomzW-

19 Vid. Aschenkindel (Summer 2016).

$20 \quad$ Vid. Lunar Chronicles (Meyer 2016). 
ko0sMxi2aw $\# \mathrm{v}=$ onepage\&q=Non\%20Violence\%20Communication $\% 20 \mathrm{~A} \% 2$ Olanguage\%20 of\%20Life\%20Rosenberg\&f=false.

SHOWALTER, E. (1977). A Literature of Their Own: British Women Novelists from Bronte to Lessing. Princeton: Princeton University Press.

SUMmer, H. (2016). Aschenkindel, Das wahre Märchen. Hürth: Drachenmond Verlag. WOLFE, D.; Wekerle, Ch.; Scott, K. (1997). Alternatives to Violence: Empowering Youth To Develop Healthy Relationships. London: SAGE Publications.

Bibliografia secundaria

ChARLO, R. (20I3). La novela popular en España. Sevilla: Secretariado de Publicaciones Universidad de Sevilla

EZELL, M. (1990). The Myth of Judith Shakespeare: Creating the Canon of Women's Literature. New Literary History 2 I (3), 579-592

Herndon, R. (1969). The German Romantic "Märchen". Modern Philology 9 (2), 239-257.

KING, L. (2000). Grand Hotel: The Sexual Politics of a Popular Culture Classic. Women in German Yearbook I5, 185-200.

KolodnY, A. (1975). Some Notes on Defining a 'Feminist Literary Criticism. Critical Inquiry 2 (I), 75-92.

MAQUIS, M. (2003). The Female Body, Work, and Reproduction in Deland, Cather, and Dreiser. Women's Studies. An inter-disciplinary Journal 32(8), 979-1 000.

Michaelis-JenA, R. (197I). Oral Tradition and the Brothers Grimm. Oral Tradition and the Brothers Grimm 82 (4), 265-275.

PARRA, E. (20I3). Destrivializando lo trivial. Reflexiones en torno a la necesidad de una nueva orientación crítico-literaria, en Parra, E. (ed.), Trivialidades literarias. Reflexiones en torno a la literatura de entretenimiento. Madrid: Visor, 9-24.

RAE, M. (1978). What Women's Literature? College English 39 (6), 653-662.

Robert, M.; L. PoWell, W. (1969). The Grimm Brothers. Yale French Studies 43, $44-$ 56.

SCHWARTZ, L. (1984). F. M. Grimm and the Eighteenth-Century Debate on Women. The French Review 58 (2), 236-243.

Weigel, S.; SpringmaN, L. (1984). Woman Begins Relating to Herself: Contemporary German Women's Literature. New German Critique 3I, 53-94.

W. Morgan, W. (1976). Feminism and Literary Study: A Reply to Annette Kolodny. Critical Inquiry 2 (4), 807-816. 
